\title{
The Landscape of a Religious Workspace: The Case of a Russian Christian Orthodox Sisterhood*
}

\author{
Ksenia Medvedeva \\ PhD Candidate, Department of Sociology, National Research University Higher School of Economics \\ Address: Myasnitskaya Str., 20, Moscow, Russian Federation 101000 \\ E-mail: ksenia-medvedeva@yandex.ru
}

\begin{abstract}
In this article, I examine the specifics of a workspace in one of the Christian Orthodox organizations in Russia. The sisterhood which I analyze represents the interlacement of religious and economic discourses in the workplace. I discuss the "commodification" of piety which is seen as a professional competency in the labour relations among Orthodox Christians. It is true about the sisterhood, where being "inchurched" is one of the main filters for potential employees. I examine the "politics of labour" in the sisterhood through the analysis of its heterogeneous spatial composition and point at the differences between its spaces in their work tempo, prestige, and working conditions. Alongside economic goals, the sisterhood is aimed at missionary and educational work; however, commercial relations are often described using religious terminology. I discuss the conflict between religious and economic aims of work. Particular attention is given to the analysis of techniques that help to maintain discipline in the sisterhood. It is achieved through rational organization of labour, observability of the workplace, hierarchy in employer-employee relationships, and the disciplining of body and emotions. The analysis is based on the materials of participant observation and field materials collected during my four months as a staff member of the sisterhood.
\end{abstract}

Keywords: Orthodox Christianity, labour discipline, work ethic, religious and economic values, "emotional work"

The concepts of discipline and control have a long history in social sciences and are connected with the idea of social order (Goffman, 1961; Coser, 1974; Foucault, 1977). Discipline can be understood as a specific regime that helps to keep the existing social order, maintains the norms established in a social group and is obligatory for its members. It arranges and rearranges people into categories, places them in a certain sequence, thus forming a specific disciplinary space within a group. The background for my research is set by the description of disciplinary practices in closed institutions. Prisons, mental hospitals, and barracks illustrate the nature of supervision and discipline precisely because they make maximum control of the behavior of their inhabitants. This paper analyzes discipline and self-discipline as an important characteristic of work management in one

() Medvedeva K., 2015

(c) Centre for Fundamental Sociology, 2015

* I would like to thank the members of the sisterhood for the experience that I received while working there in 2012-2013, and their leader for his kind permission to use the data obtained during that period. I am also grateful to Dr. Christopher Swader for his generous intellectual and emotional support. 
of the Christian Orthodox organizations in Russia. The analyzed sisterhood ${ }^{1}$ is a "community of pious single women," usually called sisters, who gathered "to help each other in their spiritual development." To perform their missionary and educational aims and carry out their daily routine they have employed workers, both men and women.

There can be highlighted several types of labour control (Kelly, 2002: 401). In this paper I focus on the individual level of a worker and examine disciplinary techniques experienced by employees themselves. I also discuss the institutional level of the company and examine the relations between the administrators and the workforce. In this research, my intention is to analyze the characteristics of Christian Orthodox work management, to clarify its working conditions, and the effectiveness of church organizations. As scholar of religion Boris Knorre notes, "The specifics of business relationship in church organizations even lose in comparison to those in a secular society" ${ }_{2}$ (Knorre, 2009). He quotes Yury Belanovsky in that the "educational and social activity of the Church is lame due to totalitarian management in church organizations." What is specific about management in church organizations? As the research shows, some church organizations tend to acquire methods of work from secular organizations. I have the experience of working and living in the sisterhood for four months as an employed worker. Using methods of participant observation and self-ethnography, I collected my field data. I also used rich materials on the sisterhood's website which contains information about its history and functioning, as well as interviews with the head of the community.

\section{The "commodification" of piety}

In recent post-Soviet years, the "Christian Orthodox labor market" has greatly developed. While after the collapse of the Soviet Union, only half of the population said it was Orthodox, by 2007 over 80 per cent claimed to be Orthodox Christians (Evans, Northmore-Ball, 2012: 799). On numerous employment websites and social network services for believers, Orthodox employers look for religious staff, and Orthodox unemployed search for "Orthodox jobs." Women seek for jobs as candle-sellers, church-cleaner jobs, as well as editors or church-singer positions. Men look for church-guard openings, as well as for website-support vacancies. The adverts of applicants usually contain common facts about education and job experience. They also may include information about the absence of certain weaknesses and ailments (for example, "no bad habits," "not homeless," "not an alcoholic"). It is interesting to pay attention to what skills and strengths they emphasize in their advertisements:

Male, 35 years old, not married, no children, looking for a job with accommodation in a church or monastery. No bad habits, know the typicon, read, sing (baritone), a professional bell ringer, photographer, not afraid of hard work. 15 years in the

\footnotetext{
1. I will designate it here as the sisterhood for the sake of anonymity.

2. Here and later all Russian terms, quotations from field notes and Russian sources are translated by the author.
} 
Church. Have a security guard license and a health book, can work in the kitchen, have experience of working in a Sunday school. Philological education. Know PC, main office programs. If anyone can help, I will be very grateful.

Interested in a courier vacancy. Salary does not matter. I will be glad to work in an Orthodox team. Inchurched Christian, parishioner of St. Alexis Church of Moscow. (Male)

As we can see, the applicants specify their core religious competencies and experience. They clearly state their religious identity and the religious community they belong to. One of the reasons why it is important is explained by Weber:

\begin{abstract}
The matter became somewhat clearer from the story of a German-born nose-andthroat specialist, who had established himself in a large city on the Ohio River and who told me of the visit of his first patient. Upon the doctor's request, he lay down upon the couch to be examined with the [aid of a] nose reflector. The patient sat up once and remarked with dignity and emphasis, "Sir, I am a member of the __ Baptist Church in __ Street." Puzzled about what meaning this circumstance might have for the disease of the nose and its treatment, the doctor discreetly inquired about the matter from an American colleague. The colleague smilingly informed him that the patient's statement of his church membership was merely to say: "Don't worry about the fees." (Gerth, Mills, 2007: 304)
\end{abstract}

As we see, giving details about one's religious life helps to build trust. Moreover, employees try to be more specific about their religious affiliation and point at their experience in religious life because they see it as their professional qualification. It helps them to stand out and be noticeable in the developing Orthodox market. Advanced market economy has commodified human relationships (Swader, 2009: 387), and being "inchurched"' is seen as a strength and an advantage of a job-hunter. This term designates believers who know the basics of their faith and are immersed in church life. Inchurchment is seen as a commodity and professional competency. An "inchurched" employee possesses certain communicative, negotiating, integrity and other skills that may be useful in a working setting. One of the openings for a manager of pilgrimage tours specified, "Novices, please do not disturb." Here are the basic requirements for a tour guide in the Valaam monastery, "Christian Orthodox confession. Knowing the basics of the Orthodox faith. Blessing from a confessor. Higher or incomplete higher education. Age: men under 60 years, women under 55 years. No health restrictions. No bad habits. Knowing a foreign language (preferable)."

The sisterhood which I analyze also demonstrates both religious and business approaches to labor. The advertisement for an opening in the sisterhood invites "inchurched

3. The Russian term votserkovlenny is usually translated as "inchurched." A person becomes votserkovlenny in the process of "churchliness" (Marsh, 2005), "in-churching" (Burgess, 2014), or "inchurchment" (Köllner, 2013) which in some sense can be compared to the process of socialization in society. It was first introduced by Russian sociologist Valentina Chesnokova in the 1990s (Chesnokova, 2005). The Public Opinion Fund used Chesnokova's methodology for their all-Russian opinion poll in 2014. Its results shows that there are about 13 per cent of "inchurched" Russians in the country (http://fom.ru/TSennosti/11587). 
hard-working women under 45 years old." During my job interview, I was asked about my age, frequency of confessing and taking communion, and knowledge of the Creed. ${ }^{4}$ In fact, I was reviewed for the compliance with the three major dimensions of religiosity: religious affiliation, religious activities, and religious belief (Bjarnason, 2007: 350). Since the sisterhood is a feminized space, in addition to these requirements, men are also expected to be married. After successful candidates pass, they become workers of the sisterhood.

\section{The labour landscape of the religious workspace}

The labour landscape of the sisterhood has heterogeneous spatial composition and is comprised of several distinct spaces. Workers from the kitchen, the church shop and the publisher differ in their status in the sisterhood, have different working conditions and follow different working requirements. These three spaces represent different "politics of labour', in which labour negotiates its wages and working conditions with employer" (Kelly, 2002: 397). Each of them occupies a separate building and has its own supervisor. I started my work in the kitchen, and after two weeks was transferred to the church shop as a member of the wholesale department and a shop assistant. Later on, I analyze some of the main differences between the workspaces of the sisterhood.

Labour spaces vary in work tempo. Directionally, from the kitchen, from the shop, and to the publisher office, I can point at the decrease in the dynamics of physical activity. The kitchen has the most dynamic regime. Work there is tied to deadlines, and there are at least three of them each day - breakfast, lunch, and dinner. Kitchen workers have to work quickly and perform several different tasks simultaneously. "Here we do not walk so slowly," said a senior sister to my roommate Irina, ${ }^{5}$ who got tired during her work. Shop is a less dynamic space, as opposed to the kitchen, and has different requirements. On my first working day in the shop I made several mistakes in the accounting statements, and my boss remarked on it, "The main thing is attentiveness, the second one is speed." Judging by the appearance, one can distinguish a kitchen worker from a shop or publisher employee. Women from the kitchen wear comfortable clothes and shoes, usually flip-flops, while women from the shop resemble typical office workers and could wear high-heeled shoes. As Irina noted, "I always hear when the shop comes for lunch, it's their clattering!"

The second difference is related to the prestige of labour spaces. When I accepted an invitation to work in the shop, and my already-ex-colleagues from the kitchen congratulated me on this promotion since the shop is a more prestigious space compared to the kitchen. The salary there is a bit higher, and it is more of an intellectual rather than physical job. One elderly woman from a Ukrainian village, probably with some experience of working in Poland, called me pani which is a way to address to women showing respect

4. Here it is important to note that knowing the Symbol of Faith is itself rare knowledge in contemporary Russia (Zorkaya, 2009: 75).

5. All names in the article are changed for the purpose of anonymity. 
in that country. This example shows the religious and economic mix in the sisterhood. On one hand, there is no better or worse place to work for a religious person who works (and more precisely "serves") "for the sake of God's glory." One the other hand, however, economic motives for work are no less important, as we see from the reaction of my colleagues.

Thirdly, each space offers its own working conditions. The sisterhood offers accommodation to its employees. Those who use this opportunity and live on the territory of the sisterhood have a longer working day, have one day off a week, and a smaller salary. They live in carefully controlled hostel environment and are subject to more control compared to shop and publisher staff. They are mostly kitchen workers who have Ukrainian background and come temporarily to earn money. However, financial motivation is not the only reason for working migrants, since "particularly strong ties to Russia exist among the religiously Orthodox population of central and eastern Ukraine" (Hormel, Southworth, 2006: 606). Being a migrant space, kitchen is very dynamic and staff turnover is frequent here because workers make periodic trips home. Moreover, dismissals are also very common here. Since they are mostly initiated by the authorities, not by the employees themselves, kitchen workers live in constant fear of being fired because no one knows who will be next. Those employees who live outside the sisterhood have shorter working days, two days off a week, and a larger salary. They are mostly Russians who work in the shop and the publisher.

Why do Orthodox economic agents work? Actually, they do not work. As Zabaev writes, "Orthodox actors do not toil, do not do business, do not work, and do not engage in a particular activity. They 'perform obediences." As he continues, "The aim is not to maximize results but to use time correctly" (Zabaev, 2007: 23). Filling in time with work helps avoid idleness, otherwise it will be occupied with sins (Zabaev, 2012: 53-54). However, in the analyzed community, time is money, and it is organized not only to be carried out correctly, but also to be effective.

A widespread work motivation among Orthodox believers is the work "to the glory of God." It is often used in the meaning of "volunteer work," or "unpaid work." Many pilgrims stay in the sisterhood and help the sisters in exchange for meals, accomodation and the opportunity to do the sights of the city. Yet, financial motivation prevails among permanent workers who are employed by the sisterhood. The popular motivation of "God's glory" gives way to a salary. As one of the employees said, "I don't work here to the glory of God, I get paid for it."

The sisterhood pursues several aims, both religious and economic. Sometimes they are in conflict with one another, and here is the story from my field notes that demonstrates it well:

One day a woman came to exchange a candlestick she had bought as it was damaged. Unfortunately, there were not any more of the same candlesticks. The problem was whether to give money back to the woman or not. The sisterhood like many church shops does not give cheques for purchases, so the refund is at the 
discretion of a certain organization. A quarrel between the customer and a senior assistant started. The customer was insisting on a refund since "these are just trading relations," as she said. While the assistant claimed, "This is your donation for the church." In the end, the assistant gave up, saying to me, "Give her the money back and let God be her judge!"

As is seen from the above quotation, commercial relations are described using religious terminology. This example does not imply that the sisterhood holds less Orthodox or more Protestant values. Actually, not only religious values and work ethic impact economic development but also a different "social ethic," which includes "social control, rule of law and homogeneity of values" (Arrunada, 2010: 895). The "social ethic" of the sisterhood is formed by the requirement of their employees to be inchurched, obey the rules and regulations of the sisterhood and their leader, and different types of social control that are carried out there. Alongside commercial goals, the sisterhood is also aimed at missionary and educational work. When I worked in the shop, I paid attention to the types of things they sell there. Among other items, the shop sells chocolates with wrappers picturing Christian Orthodox saints. Chocolates are produced at a confectionery factory, but the original wrapper is removed in the sisterhood and replaced with a "religious" one. However, if they pictured recognized saints, the chocolates would bring in more profit. But, they do not. The wrappers mostly picture little-known Christian Orthodox saints which can only point at the sisterhood's missionary and educational aim.

\section{Disciplining techniques in the work management}

The spatial composition of the sisterhood is quite diverse, and each workplace has its own disciplinary regime. The workforce is subject to both horizontal and vertical disciplining (Kharkhordin, 1998: 960). I have identified several techniques that help to maintain discipline. They are rational organization of labour, observability, hierarchy, and "emotional work."

Work in the sisterhood is organized rationally. Like many other church organizations today, the sisterhood employs accountants and has much paperwork in the wholesale department. Moreover, at the individual level, each worker is also involved in "rational book-keeping" (Weber, 2001: xxxv). Every workday, workers write down the times when they begin and end work. Only registered time is paid for. The kitchen staff has one more kind of "disciplining book-keeping": if a worker breaks some utensil, she should write down her name and what the broken item was into a special kitchen journal. When pay day comes, an amount of money for a broken item will be held back from her salary. Another characteristic of rationally organized labour process is the accumulation of capital and its investment (Weber, 2001), which in the sisterhood takes the form of expanding: the community started with one main venue more than ten years ago, and nowadays it has three more affiliated churches which vary in size. As many Christian Orthodox companies in Russia, they pursue not only religious aims in their work, but also work to earn a profit 
(Mitrokhin, 2000). More precisely, they invest the earned money into their missionary, educational, and religious projects. The head of the sisterhood believes that "the economics of the Church should be modern." In his opinion, they should earn money themselves, which "is more proper than scrounging on non-parishioners."

Mutual control is best performed in the kitchen since it is the most observable space. In this situation, working together functions as supervision. Being physically available for visual control itself disciplines the workers. It is achieved owing to interior layout: the rooms in the kitchen create one sightline, and its doors are almost always open so that it creates a feeling of one large place. However, more self-control is required when working in the shop. The shop has fewer employees and its space is divided into separate rooms, many of which are equipped with combination locks, making it difficult to quickly move from one place to another. Each employee works at their computer station, or at their counter. That is why a different method of workers' control appears, that of an indirect one. Disciplining is mediated by posters and various notes hanging on the walls and doors which dictate how to behave and how not to behave. One of these notes on a bookcase says: "If one hides a case of disorder from the authorities, then how can they be safe and not afraid, that ten cases are not hidden?' St. Philaret of Moscow." This quote performs a controlling function and acts on behalf of a well-known thinker who is respected among the Orthodox.

In general, one's attention can be attracted by the numerous notices on the walls of commonly-used places. They are written by the sisters and regulate what should or should not be done, and how certain objects should or should not be used. These adverts contain both prohibiting and permissible guidance. Notices often use excessive words to enhance the meaning of a word, and create some redundancy in the notes. In cloakrooms, washrooms, and workplaces, there is information on how to behave, what to do and what not to do. It may indicate that many new people circulate in this organization. At the same time, these notices create a dialog situation, as if a worker is not alone, and can act as disciplining tools to check one's work by involving a worker into this dialogue. In the sisterhood, there is an ironing room with one iron shared by all the workers who live there. One day, we found it broken. The notice on the broken iron had a sad smiley at the end. It said, "Someone who broke this iron (or knows anything about it) is asked to honestly confess it to the hotel-keeper. Otherwise you and your neighbors will have to get along without the iron:(" The end of the story remains unknown to me, but even the notice is one more example of the self-discipline that is quite important in the sisterhood.

Like many other religious organizations, the sisterhood is hierarchical and patriarchal. The head of the sisterhood is its confessor, who is also its spiritual father and founder. Work in the sisterhood is organized under his guidance through the system of 'blessings.' Being one of the main categories of work ethics of Orthodoxy (Zabaev, 2012), blessing is important because it fixes the mentioned hierarchy of the sisterhood. The confessor gives blessings to the sisters, and the sisters give blessings to the workers. The original meaning of "blessing" is an "invocation of divine grace ... onto a person who asks for 
it." ${ }^{6}$ However, it also has some disciplinary connotations. The term "blessed" may refer to the sphere of something permitted as opposed to prohibited. It can also be used to signify the order of the authorities (for example, in the notice: "Attention! New blessing!") It covers the sphere of one's duties since a worker can be fined for not "fulfilling" a blessing. As one of the notices in the kitchen reads, "Dear soup-cookers! Batyushka blessed to use frozen greens when cooking soup. For non-fulfillment - money penalty." It can even be expressed in the form of likes and dislikes, as in this field note: "Once I came to the shop wearing mascara, and received a remark from a senior sister in the shop: 'Batyushka' doesn't like when somebody uses lash mascara."

According to Foucault (1977), the subject of punishment over time moves from the body of the offender to his "soul." The sisterhood demonstrates both body discipline and the disciplining of emotions. The discipline of the body is an important aspect of life in the sisterhood. There are penalties for those who are careless about their health. For example, if a person goes out in the street without outer clothing, he or (mostly, as there are more women in the sisterhood) she can get a remark, and even be fined. Slow and ill workers are often sacked.

The workers should meet certain requirements which apply to clothes and cosmetics. Women should not use cosmetics, they should cover their head with a scarf, and they should wear a skirt with a regulated length of being below the knees. Such requirements can be seen as a certain "work uniform," since not all female workers wear such skirts in their everyday. It can be illustrated by a record from the field diary, "At the end of the working day my young colleague of 22 years old changed one skirt into another: she took off her 'working' long skirt and put on a mini-skirt, in which she went home. Orthodox uniform!" (October 10, 2012) The workers from the publisher seem to be more independent of the sisterhood's appearance requirements, since female workers from the publishers sometimes wore trousers and did not have a scarf. However, requirements in appearance exist in many organizations, not only in religious workplaces. They help to create the special atmosphere of that place and fit the expectations of their customers. It is true about the church shop since customers expect it to be a truly Orthodox place. Still, these requirements refer to the sphere of religious ethic rather than work ethic since female workers should observe these rules even in those workplaces where customers do not see them. No one except sisters and other employees see the women in the wholesale department and the kitchen, but still those women have to dress properly. Meeting these appearance standards creates the atmosphere of an Orthodox workplace.

One more method of disciplining is through "emotional work" (Hochschild, 1983). The work in the sisterhood is quite emotional because the disciplining methods appeal to individual workers, their conscience and religious beliefs. Disciplining the soul, raising morals, and the social nature of emotions are quite popular topics in social sciences.

6. Christian Orthodox website "Azbuka very" [Introduction to faith]: http://azbyka.ru/dictionary/o2/ blagoslovenie.shtml.

7. "Batyushka" is a very common, gentle way of addressing to priests and speaking about them, that is, an informal version of the word "father." 
Charles Cooley (2013) points out that this topic has been widely discussed in the literature about spiritual life, and adds, "The prophets of the inner life, like Marcus Aurelius, St. Paul, St. Augustine, Thomas a Kempis, and Pascal, were men distinguished not by the lack of an aggressive self, but by a success in controlling and elevating it, which makes them the examples of all who undergo a like struggle with it" (Cooley, 2013: 248-249). There are two ways of controlling the social "I." The negative way is to avoid anything that could excite the emotions, and the positive way is to oppose, control, and direct the emotions. The second method, the author believes, is a traditional part of the religious discipline of consciousness.

Directing emotions is important for the employees. Conflict resolution skills are essential for working in the sisterhood. If a conflict situation happens and is not solved for some reason, one of the conflicting parts is usually fired. The slightest hints of dissatisfaction are suppressed (Tocheva, 2014: 20). Asking for forgiveness has become an institutionalized practice in the community since it is part of the senior sister's work in the kitchen (part of her "obedience"). Each time after having a meal, she stands in front of the other sisters and says, "Sisters, sorry for a badly cooked meal." It is hardly common in secular workplaces, and it adds an emotional connotation to the kitchen space. Emotional work among the workers is directed towards colleagues rather than customers and lies within the employer-employee and the employee-employee spheres. Moreover, as the example with the candlestick shows, a customer can be wrong.

There is an area with less supervising in the sisterhood. This "shadow zone" is closely tied to the gender issue. The sisterhood is a highly feminized workplace. Sisters hold managerial positions there, and even a lorry fleet is run by a sister. It contradicts the common view on women's secondary status in the secular labour market and their "inferior job opportunities vis-a-vis men" because alongside the roles of "workers and mother" it offers one more female scenario in terms of consecrated life (Ashwin, Yakubovich, 2005: 159). There, the "shadow zone" is the book warehouse where mostly men work. At the entrance of the warehouse, the words "The territory of freedom" were scrawled. The warehouse is a place where irony affects not only interpersonal relations, but also labor relations: people joke about their work here much more than in other more feminized workplaces. As elsewhere in the sisterhood, the warehouse has many notices on the walls. However, these notices are creatively edited by the warehouse staff. Here, humor and irony soften the rigor of the posters. For example, on one of the notices, an exclamation mark was turned into a smiley. The warehouse is a space where informal creativity reigns. The walls have drawings, pictures, and quotes about life, love, and religion, though not only from the Holy Fathers. Thus, in the sisterhood, gender issue is connected not only with job opportunities but also with the control over workspace.

\section{Conclusion}

In this paper, I analyze the specifics of work management using the case of a Russian Orthodox sisterhood and give a brief outline of the Christian Orthodox labour market. Like 
many Church organizations in the post-Soviet period, the sisterhood is characterized by a mix of religious and economic features. It pursues several aims, both religious and economic. On one hand, they may contradict one another and cause conflicts; on the other hand, they may complement each other: thus, the capital accumulated in the sisterhood is invested into religious missionary and educational projects. Work in the sisterhood is aimed at results, and profits are achieved by a particular style of management. However, as in many religious organizations, being "inchurched" is an important requirement of potential employees in the sisterhood which serves as a filter in the job marketplace. It acts as a commodity and indicates professional competency rather than a personal trait of character. One more evidence to the religious-economic fusion in the sisterhood is that economic relations are described using religious categories.

"Labour politics" of the sisterhood is played out at different levels, and "control and regulation operate simultaneously at multiple scales" (Kelly, 2002: 409). I give an ethnographic account of labour discipline and work management in the three major spaces of the sisterhood: the kitchen, the shop, and the publisher. I analyze the difference between the spaces in terms of their work tempo, prestige, and working conditions. The kitchen has the most dynamic regime of work and is the least prestigious space. Those who work in the shop and the publishers have more stables jobs and a higher salary. Thus, the difference in working conditions creates more and less prestigious jobs within a religious environment.

I deconstruct the spatial composition of the sisterhood to show how the various types of control are performed there. Each workplace has its own disciplinary regime which is maintained owing to rational organization of labour (book-keeping, accounting), direct and indirect visual control over the workplace, hierarchy in the relationships between the administrators and the employees fixed by the categories of obedience and blessing, and the disciplining of body and emotions. At the same time, self-discipline is also required from workers and is quite important in the work management in the given community.

Work management of the sisterhood characterizes new tendencies in the present-day Russian Orthodox labour market in general and provides evidence that the market has a complex religious and economic nature.

\section{References}

Arruñada B. (2010) Protestants and Catholics: Similar Work Ethic, Different Social Ethic. Economic Journal, vol. 120, no 547, pp. 890-918.

Ashwin S., Yakubovich V. (2005) Cherchez la femme: Women as Supporting Actors in the Russian Labour Market. European Sociological Review, vol. 21, no 2, pp. 149-164.

Bjarnason D. (2007) Concept Analysis of Religiosity. Home Health Care Management and Practice, vol. 19, no 5, pp. 350-355.

Burgess J. P. (2014) In-churching Russia. First Things: A Monthly Journal of Religion and Public Life, no 243, pp. 37-43. 
Chesnokova V. (2005) Tesnym Putem. Process Vocerkovlenija Naselenija Rossii v Konce XX Veka [The Narrow Way. The Process of Inchurchment of the Russian Population at the End of the 20 Century], Moscow: Akademicheskij proekt.

Cooley C. H. (2013 [1922]) Human Nature and the Social Order, London: Forgotten Books.

Coser L. A. (1974) Greedy Institutions: Patterns of Undivided Commitment, New York: Free Press.

Evans G., Northmore-Ball K. (2012) The Limits of Secularization? The Resurgence of Orthodoxy in Post-Soviet Russia. Journal for the Scientific Study of Religion, vol. 51, no 4, pp. $795-808$.

Foucault M. (1977) Discipline and Punish: The Birth of the Prison, New York: Random House.

Gerth H. H., Mills C. W. (eds.) (2007) From Max Weber: Essays in Sociology, London: Routledge.

Goffman E. (1961) Asylums: Essays on the Social Situation of Mental Patients and Other Inmates, New York: Anchor Books.

Hochschild A. (1983) The Managed Heart, Berkeley: University of California Press.

Hormel L., Southworth C. (2006) Eastward Bound: A Case Study of Post-Soviet Labour Migration from a Rural Ukrainian Town. Europe-Asia Studies, vol. 58, no 4, pp. 603623.

Kelly Ph. F. (2002) Spaces of Labour Control: Comparative Perspectives from Southeast Asia. Transactions of the Institute of British Geographers, vol. 27, no 4, pp. 395-411.

Kharkhordin O. (1998) Civil Society and Orthodox Christianity: First Europe-Asia Lecture. Europe-Asia Studies, vol. 50, no 6, pp. 949-968.

Knorre B. (2009) Pravoslavie v Rossii i 20-letnee ispytanie svobodoj [Orthodoxy in Russia and the Twenty-Year Test with Freedom]. Russian Review. Available at: http:// www.keston.org.uk/_russianreview/edition35/o2-knorr-about-father-peter-mescherinov.html (accessed 20 March 2015).

Marsh C. (2005) Russian Orthodox Christians and their orientation toward Church and state. Journal of Church and State, vol. 47, no 3, pp. 545-561.

Mitrokhin N. (2000) Russkaja pravoslavnaja cerkov' kak sub'ekt jekonomicheskoj dejatel'nosti [Russian Orthodox Church as the Subject of Economic Activity]. Voprosy Jekonomiki, no 8, pp. 54-70.

Swader C. (2009) Adaptation as "Selling Out"?: Capitalism and the Commodification of Values in Post-Communist Russia and Eastern Germany. Journal of International Relations and Development, vol. 12, no 4, pp. 387-395.

Tocheva D. (2014) The Economy of the Temples of God in the Turmoil of Changing Russia. European Journal of Sociology, vol. 55, no 1, pp. 1-24.

Weber M. (2001 [1930]) The Protestant Ethic and the Spirit of Capitalism, London: Routledge.

Zabaev I. (2007) Osnovnye kategorii hozjajstvennoj jetiki sovremennogo russkogo pravoslavija [Main Categories of Economic Ethic in Modern Russian Orthodoxy]. Social'naja Real'nost', no 9, pp. 5-26. 
Zabaev I. (2012) Osnovnye kategorii hozjajstvennoj jetiki sovremennogo russkogo pravoslavija: sociologicheskij analiz [Main Categories of Economic Ethic in Modern Russian Orthodoxy: A Sociological Analysis], Moscow: PSTGU.

Zorkaja N. A. (2009) Pravoslavie v bezreligioznom obshhestve [The Orthodoxy of the Society without Religion]. Vestnik obshhestvennogo mnenija: Dannye. Analiz. Diskussii, no 2 (100), pp. 65-85.

\title{
Трудовая дисциплина в православном сестричестве в России
}

\author{
Ксения Медведева \\ Аспирант департамента социологии Национального исследовательского университета «Высшая школа \\ экономики» \\ Адрес: ул. Мясницкая, д. 20, Москва, Российская Федерация 101000 \\ E-mail: ksenia-medvedeva@yandex.ru
}

В этой статье я рассматриваю особенности рабочего пространства в одной из православных организаций в России. Сестричество, которое я анализирую, представляет собой переплетение религиозных и экономических дискурсов в рабочем пространстве. Я поднимаю вопрос «коммодификации благочестия», которое используется как профессиональная компетенция в трудовых отношениях среди православных христиан. Это верно в применении к сестричеству, где «воцерковленность» является одним из основных фильтров для потенциальных сотрудников. Я разбираю «политику труда» в сестричестве через анализ гетерогенной пространственной композиции и отмечаю различия между рабочими пространствами, в частности, темп работы, престиж, условия труда. Помимо экономических целей, сестричество преследует миссионерские и образовательные задачи; тем не менее, рыночные отношения часто описываются с помощью религиозной терминологии. Я анализирую конфликт между религиозными и экономическими целями труда. Особое внимание уделяется анализу техник, которые помогают поддержать дисциплину в сестричестве. Это достигается через рациональную организацию труда, наблюдаемость трудового пространства, иерархию в отношениях руководительподчиненный и дисциплинирование тела и эмоций. Исследование основано на материалах включенного наблюдения и полевых данных, собранных за четыре месяца, проведенные мною в качестве сотрудницы сестричества.

Ключевые слова: православие, дисциплина, трудовая этика, религиозные и экономические ценности, «эмоциональная работа» 